\title{
EL CINE ESPAÑOL COMO FUENTE DOCUMENTAL PARA EL ESTUDIO DE LOS BARRIOS MARGINALES
}

\author{
Aramis López Juan \\ Museo de la Universidad de Alicante
}

\section{RESUMEN}

El cine como arte nuevo y técnico se instala en una sociedad moderna que tiene una percepción del mundo basada en la imagen. El cine y la fotografía son los introductores de esta modalidad perceptiva de la modernidad. Esta experiencia sensorial sitúa al hombre en un universo más amplio. El hombre contemporáneo comprende los mecanismos representativos del cine, sus códigos, sus metáforas e iconos. El cine ha nacido al mismo tiempo que los abuelos de los espectadores actuales, ha crecido con sus padres, y es conocido y comprendido universalmente.

Palabras clave: Cine, percepción, suburbios, marginalidad, fotografía.

\section{ABSTRACT}

The cinema like a new art is installed in a modern society has a perception of the world based on the image. The film and photography are the initiators of this perceptual mode of modernity. Usually the citizen perceive the urban models through the knowledge previus based in film images, not with the real images.

Key words: Cinema, perception, suburbs, marginal, photography.

\section{Introducción}

Desde que en 1895 el cinematógrafo fue inventado por los hermanos Lumière, nace una nueva técnica de representación de imágenes, sobre todo un nuevo espectáculo colectivo. A partir de ese momento las películas se convirtieron en parte fundamental del ocio de innumerables espectadores, nació el séptimo arte, y con él una de las mayores fuentes de información y conocimiento a las que tiene acceso un individuo en cualquier lugar del mundo. 
El cine como arte nuevo y técnico se instala en una sociedad moderna que tiene una percepción del mundo basada en la imagen. El cine y la fotografía son los introductores de esta modalidad perceptiva de la modernidad, esta experiencia sensorial sitúa al hombre en un universo más amplio. El hombre contemporáneo comprende los mecanismos representativos del cine, sus códigos, sus metáforas e iconos, esto le permite recibir mucha información en un tiempo reducido, recordar los conocimientos adquiridos asociados a elementos de representación visual y sonora. El cine ha nacido al mismo tiempo que los abuelos de los espectadores actuales, ha crecido con sus padres, y es conocido y comprendido universalmente.

Cabe destacar con relación a los conocimientos que el cine proporciona la verosimilitud que se atribuye al propio medio. El cine y la fotografía eran considerados como traslaciones fidedignas de la realidad a un soporte físico y perdurable. La idea de realidad de lo representado en imágenes lleva a Jean Baudrillard a interrogarse en relación al mundo que conocemos a través de las imágenes, y sobre que hay de realidad en lo irreal y de irrealidad en lo real, dicho de otra forma, ¿sucede aquello que es representado?, o ¿no sucede lo que no es representado?, en 1991 escribía tres artículos recogidos en Baudillard (2000) con los siguientes títulos: La Guerra del Golfo no tendrá lugar (4 de enero), ¿Está teniendo lugar realmente la Guerra del Golfo (6 de febrero) y La Guerra del Golfo no ha tenido lugar (29 de marzo). La duda sobre la realidad y ficción en el cine es una de las mayores potencialidades de este ya que permite establecer reflexiones personales sobre la propia realidad del espectador.

A través de estas consideraciones se podría plantear que el cine permite reflejar situaciones comunes a través de los códigos universalmente conocidos y contiene información abundante sobre las ciudades, por ello ¿por qué no hacer uso de él como fuente documental para su estudio?, las posibilidades cognitivas, e incluso simbólicas del cine podría permitir un acercamiento a realidades desconocidas, distantes, a una ingente cantidad de datos y de informaciones recogidas en la numerosa filmografía existente.

El cine cuenta aproximadamente con un siglo de historia. Durante el siglo XX asistimos a la transformación de la red urbana española. Los fenómenos migratorios vacían el campo español y configuran una nueva distribución de la población basada en un modelo urbano frente al rural preexistente. Es por lo tanto lógico pensar que un arte como el cinematográfico, que tiene una gran inmediatez con el público, haya recogido estos procesos migratorios y la posterior adecuación de la población a sus nuevos entornos ciudadanos.

El cine nace como un espectáculo alejado y denostado por las clases intelectuales, burguesas o adineradas. En España el primer intelectual que se acerca con verdadero interés al nuevo medio es Jacinto Benavente que funda incluso una productora cinematográfica, Films Benavente, pero esto sucede cuando ya han pasado treinta años de la irrupción del cine en nuestro país. Como el cine es un espectáculo barato goza del favor de las clases populares. La temática de sus películas de argumentos recoge historias cercanas a las vivencias y anhelos de los ciudadanos que acuden a las proyecciones cinematográficas.

Pero, ¿hasta qué punto las realidades mostradas por el cine son reflejo fidedigno de los proceso que acontecen en el medio urbano? ¿Cómo establecer los límites de aquello, que mostrado por el cine, es pura invención que pertenece a la trama de la historia, y aquello que es información contrastable con la realidad cotidiana? Podemos partir de la idea de que el fin de las películas no es el de mostrar los procesos urbanos como base para estudios científicos. Las películas de ficción muestran historias más o menos reales, sobre los asuntos más diversos, pero la credibilidad de su argumento depende en gran medida de lo real que se muestren todos los aspectos que rodean a la historia que se presenta. 
Las obras artísticas nos hablan no solo de las historias que relatan o de las imágenes que reflejan sino también del momento histórico en que se crean. La interacción entre película y contexto histórico se da en los dos sentidos, se puede incluso afirmar que algunas películas han tenido influencia en los contextos en los que surgieron, puede tomarse como ejemplo de ello la importante influencia de la filmografía de Pedro Almodóvar en los comportamientos y modas en la España de los años ochenta.

\section{El cine y el barrio marginal}

Las películas ponen en contacto al investigador con hechos vitales de gran importancia a los que no se llega a través de las fuentes tradicionales. Se trata de cuestiones como: la opinión pública, las modas, los hábitos alimenticios, el sentido del humor de la época en la que está filmada, las condiciones sanitarias, los medios de comunicación, o las informaciones de tipo subjetivo, emocional o de creencias.

Debemos señalar que para la utilización del cine español como fuente documental se han de tener algunas consideraciones previas.

Hasta la década de los años cincuenta no se generaliza la utilización de los llamados escenarios naturales, es decir, el uso de las localizaciones reales no es habitual hasta que no se da un avance en las técnicas de filmación. Esto no significa que en las producciones anteriores la ciudad no sea un asunto relevante, pero son realizaciones que aún hablando de la ciudad y de las historias que en ella acontecen no utiliza con abundancia imágenes reales.

Otra cuestión fundamental a tener en cuenta al hacer uso del cine es la disponibilidad de material, tanto en lo que ser refiere al número de películas como a su conservación. Durante la década de los años treinta se producen una media de veinte largometrajes anualmente, cifra que se incrementa hasta casi cuarenta al año en la siguiente década, entre cincuenta y setenta películas es la media de producción anual hasta la década de los ochenta y aproximadamente entre sesenta y noventa películas como máximo hasta el año 1992 y entre setenta y cien hasta nuestros días.

\section{Descripción morfológica de los enclaves de marginalidad a través del cine}

El cine español ha tenido a lo largo de sus cien años de historia aproximada dos focos fundamentales de producción: Barcelona y Madrid. El resto de las ciudades españolas presentan un número de producciones anecdótico, solamente Valencia tiene en algún momento cierta industria cinematográfica. Durante las décadas de los años ochenta y noventa, el fomento a la producción cinematográfica por parte del gobierno vasco aumento significativamente el número de producciones en el País Vasco, según datos de la propia Filmoteca Vasca (1995).

El estudio de los espacios de marginalidad en las ciudades españolas se puede abordar con suficiente material en el caso de Madrid y Barcelona, y puede encontrarse material interesante para otras ciudades españolas:

Madrid tiene como localizaciones fundamentales, para el estudio de la marginalidad, dependiendo de la morfología urbana representada:

\section{Centros históricos}

- Lavapiés. La Plaza de Lavapiés; las calles de Avemaría y Magdalena; la Plaza de Tirso de Molina y Antón Martín; establecimientos característicos como el bar Económico o el Barbieri. 
Es el barrio de la inmigración por antonomasia, desde Surcos (José Antonio Nieves Conde, 1950), hasta producciones actuales como La fuente amarilla (Miguel Santesmases, 1999) o Descongélate (Félix Sabroso y Dunía Ayuso, 2003). Ha representado el lugar de llegada a Madrid de las migraciones interiores hasta los años ochenta en que el origen de los inmigrantes es extranjero, se convierte en el paradigma del mestizaje en las representaciones más actuales.

- El Rastro. La Ribera de Curtidores, la Plaza de Cascorro y los alrededores han sido y continúan siendo escenario natural de numerosas realizaciones, Mi tío Jacinto (Ladislao Vajda, 1954), Los chicos (Marco Ferreri, 1957), Bajarse al Moro (Fernando Colomo, 1984),... El fenómeno de la delincuencia está asociado a este enclave madrileño. En él se pueden ver las ventas de productos robados en el mercadillo dominical y en los establecimientos allí situados. Es el hábitat natural de maleantes.

- Los márgenes del río Manzanares al sur de la ciudad, el Barrio de Legazpi..., son utilizados frecuentemente para escenificar las situaciones de mayor pobreza.

- Del resto de localizaciones del centro histórico de Madrid que se utilizan ocasionalmente o de forma parcial podemos destacar, el barrio de Embajadores, los alrededores de la Puerta del Sol y de la Plaza Mayor, el Madrid de los Austria,... Suelen ser utilizados para contextualizar la acción en la ciudad histórica, y aunque sin duda en ellos se dan fenómenos de marginalidad no son localizaciones que se asocien a este concepto.

\section{Suburbios}

- El suburbio madrileño tiende a representarse como genérico. Es decir, no se suele saberse que localización concreta se está mostrando, en el caso de Barrio (Fernando León, 1999) la filmación que pretende describir la vida de tres adolescentes en un suburbio madrileño se efectúo en cinco barrios distintos (Carabanchel, La Elipa, San Blas, Aluche y San Cristóbal de los Ángeles). ¿Qué he hecho yo para merecer esto? (Pedro Almodóvar, 1984) sucede en el Barrio de la Concepción pero no se hace referencia a la localización en ningún momento en la película.

- Los llamados barrios de absorción, es decir, aquellos cuya construcción esta fomentada por medidas gubernamentales para reubicar a la población previamente instalada en chabolas, presentan dos connotaciones bien diferenciadas si se trata de producciones de directores afines al régimen o de cineastas disidentes. En El inquilino (José Antonio Nieves Conde, 1957), la censura impuso la modificación del final de la película - en el original una vez derruida la casa, el protagonista y su familia se instalan en la vía pública al no poder conseguir vivienda - en el que rueda por imposición a la productora del Ministerio de la Vivienda, familia consigue solucionar el problema al encontrar alojamiento en uno de estos barrios de absorción al que se llama Barrio de la Esperanza.

\section{Chabolas}

- Los tradicionales barrios de chabolas: El Pozo del Tío Raimundo, Cerro del Tío Felipe Pío, Cerro de Valderribas, Colonia de la Inmaculada,... no son identificados en los rodajes. No suelen constituir el escenario donde trascurre la acción mayoritariamente salvo en, Cerca de la ciudad (Luis Lucia, 1952), uno de los pocos ejemplos en los que la acción transcurre en un barrio de chabolas, concretamente en el Pozo del Tío Raimundo. En caso de producciones como Tiempo de silencio (Vicente Aranda, 1986) se trata de una reconstrucción muy posterior, que informativamente resulta 
también interesante. Su proliferación corresponde a la etapa en la que el gobierno, que no podía obviar su existencia, no era excesivamente partidario de su exhibición.

Barcelona tiene una imagen más normalizada que otras ciudades españolas. Atendiendo a la morfología urbana representada podemos significar:

\section{Centros históricos}

- El Barrio Chino, que en la actualidad se denomina el Raval, dentro del distrito de Ciutat Vella, es el emplazamiento característico de la marginalidad en la representación cinematográfica de la ciudad. Presenta unas particularidades que lo convierten en un personaje más de las películas allí rodadas. Su proximidad al Puerto de Barcelona, que le confiere hasta la década de los sesenta un carácter cosmopolita difícilmente igualable en el resto de la península. Su significante es sinónimo de prostitución, favorecida por la llegada de los marineros a puerto, pero también por el resto de barceloneses e incluso de individuos llegados de fuera de los límites de la propia ciudad, en un fenómeno precursor del actual turismo sexual. Hasta que inicia su decadencia a partir de los años setenta sirve como escenario de aquellas secuencias en las que se pretende dar una idea de diversión, las juergas se ruedan en el Barrio Chino gracias a la existencia de numerosos locales. Tiende a mostrarse siempre populoso y dispuesto a recibir a cualquier hora. A partir de los años ochenta varía su caracterización, es un barrio marginal en decadencia, con abandono de los inmuebles que presentan un gran deterioro. Sirve de escenario a la representación de la pequeña delincuencia; la inseguridad que vemos va asociada a procesos de drogadicción. La prostitución ha disminuido y suele tratarse de adictas que no presentan el aspecto atractivo que poseían las chicas del pasado. La imagen del barrio se asocia con cierta idea de nostalgia.

\section{Suburbios}

- Al igual que Madrid los rodajes en barrios de nueva construcción no suelen identificar sus localizaciones, pero podemos distinguir dos tipologías claramente: el barrio obrero, donde residen los trabajadores industriales, en los que podemos ver fenómenos de inmigración, pobreza, pero no de delincuencia y los barrios propios de la criminalidad, que aparecen con la moda de las películas de delincuencia juvenil. Son los barrios de La Mina, Campo de la Bota, Zona Franca, alrededores del Cementerio de Montjuitch,...

\section{El entorno del barrio marginal}

El cine nace como un fenómeno ligado a la ciudad, los primeros estudios de grabación están en las ciudades, los actores viven en ellas, toda la industria cinematográfica está ligada al entorno urbano, durante la historia del cine se han hecho películas en ciudades, para públicos urbanos y con historias que se desarrollan en ciudades.

En el lenguaje cinematográfico son usualmente utilizados los llamados motivos visuales, que como describe Balló (2000:11-20) son metáforas que contienen una gran significación y cuya codificación es conocida por el público en general. Los motivos visuales de carácter urbano describen una serie de condicionamientos vitales que la ciudad impone a los ciudadanos, son situaciones vividas por el espectador, que se perciben con facilidad, y que permiten participar de la historia representada al darse una relación de familiaridad con el ambiente en el que se desarrollan. 
La ciudad para los realizadores afines al régimen franquista presentaban unas características favorables a la dictadura. Son lugares donde es posible la vida cómoda, en ellas se dan unas condiciones de vida mejor evolucionadas que en el medio rural, poseen los atractivos del desarrollo, las posibilidades de progreso personal, el acceso a la cultura y el ocio diversificado, y mejores condiciones higiénicas y sanitarias. Los ambientes marginales son sustraídos por lo general a la visión pública, pero cuando aparecen su caracterización dista mucho de ser realista.

En el llamado cine de la disidencia (usando el término acuñado para determinadas producciones de los años cincuenta) los ambientes marginales permiten con sólo su exhibición ejercer una crítica a los fracasos de la política gubernamental. Además encuentran en los sectores más desfavorecidos de la sociedad la posibilidad de mostrar las contradicciones que la idea de liberalismo capitalista impone en las ciudades, y según Monterde (1995: 239-293), de qué manera la degradación del modelo urbano que supone el barrio marginal influye en el devenir personal del individuo.

La imagen del pueblo siempre es antónima de la de la ciudad. Puede ser el medio rural mostrado como negativo contraponiéndolo a la ciudad como prosperidad, futuro y bienestar. $\mathrm{O}$ al contrario cuando se pretende ensalzar la vida sana y honesta del pueblo frente a la degradación de la vida urbana.

La degradación que presentan los actuales barrios históricos provoca una visión melancólica y romántica desde las realizaciones cinematográficas. Los centros históricos contienen la idea de ciudad, son su núcleo fundacional, y es en ellos donde se encierra el alma y la personalidad de las ciudades.

Los suburbios a partir del cambio de régimen en España han sido representados en el cine como factorías de delincuentes, drogadictos e individuos frustrados y sin futuro. Según Trashorras (1998: 83-112), las imágenes de los bloques de viviendas llevan asociados de inmediato la idea de entorno hostil. En numerosas escenas los personajes antes de morir o de suicidarse miran las fachadas de los bloques de viviendas, estos planos son rápidamente asimilados por el espectador y han contribuido a incrementar la imagen negativa del suburbio español.

Al inicio de la película Barrio se muestra una tipificación de las imágenes que corresponden al concepto marginación. Se trata de una batería de planos que como en muchos otros casos nos describen en pocos segundos cual es el entorno que condiciona la vida de los personajes: una pelea en la calle, un anciano durmiendo en el suelo, dos individuos pidiendo a los conductores en un semáforo, un perro con bozal en actitud agresiva, unos muchachos jugando al fútbol en un descampado, una tremenda acumulación de bloques de viviendas iguales, niños andando sobre unas vías de tren en una zona llena de pintadas, jóvenes consumiendo alcohol en un descampado, una joven inmigrante vendiendo periódicos a los conductores, gitanos con una cabra, una anciana escarbando en un contenedor de basuras, varias escenas de venta de drogas y como colofón nuevamente los bloque de viviendas.

Algo que la representaciones cinematográficas de los barrios marginales nos muestran es la heterogeneidad del paisaje. Encontramos en centros históricos edificaciones contemporáneas a la narración, y en suburbios, restos de las casas que formaban parte del núcleo originario de carácter periurbano. Las chabolas o barracas pueden aparecer en poblados aislados, en los márgenes, o en los intersticios de los barrios suburbiales.

Muchos barrios al evolucionar presentan construcciones diversas, son acumulaciones de varios tipos de construcciones, pero también de diferentes situaciones vitales. Pueden perder su carácter marginal al mejorar de forma generalizada la coyuntura económica de sus habitantes, o degradarse por abandono o crisis. Estas variaciones morfológicas son recogidas en el cine, pero también lo son las explicaciones sobre las causas que han motivado los cambios. 
En las películas encontramos entornos diferentes, lugares que no son motivo de estudio, pero que resultan emocionalmente imprescindibles, como es el caso del descampado. Los descampados son lugares para el ocio sin intermediarios, sin costes, son propiedad de los que carecen de todo. Son lugares donde se abocan los desechos de una ciudad acomodada, desperdicios que se convierten en tesoros para los marginados. Son incontables las secuencias en las que se muestran grupos de desheredados sociales que recogen las escorias en vertederos, basuras de una sociedad rica que son el sustento de otra pobre. En ellos el paisaje marginal se iguala y globaliza: Madrid, París, Barcelona o Roma no representarían escenarios diferentes. Continuamente se muestran en los filmes estos espacios marginales periféricos, lugares entre las autopistas y los bloques de viviendas, entre zonas industriales o centros comerciales. Los personajes fílmicos, que representan realidades muy concretas, convierten estos espacios en sus lugares de ocio. Las zonas menos civilizadas del mundo occidental son estas periferias de las grandes ciudades, estos espacios marginales en los límites de lo urbano donde se dan las verdaderas comunidades libertarias, la única anarquía urbana posible, los únicos reductos donde las leyes que rigen para la ciudad no se pueden aplicar.

\section{Personajes de la marginalidad fílmica}

Los personajes marginales en el cine español son representados de forma muy diversa según: si se tratan de producciones con un intención crítica respecto a la situación social o por el contrario no presentan un sesgo disidente. En estas últimas, los personajes marginales se suelen caracterizar como seres humildes de situación y de carácter, ejemplifican un status de inferioridad. Podemos hablar de dos grados de pobreza, degradación y marginalidad que presentan los personajes: el de los protagonistas y el de aquellos que están peor. Esto posibilita que el espectador que se identifica con los protagonistas valore de forma positiva su situación personal aunque ésta diste mucho de ser óptima.

En cambio, para el cine disidente son personajes frustrados, sin esperanza, ni posibilidad de mejora para el futuro. Cuando se tratan de personajes protagonistas su comportamiento dista de ser heroico, procuran su supervivencia y la de su entorno inmediato. Conocen el mundo de la miseria en el que viven, pero no conocen el de la opulencia, sólo lo imaginan, y casi siempre de forma distorsionada.

El barrio y su entorno vital, las condiciones en las que se han de desarrollar su existencia son mostradas como el agente activo de las desgracias de los personajes. Abundan las escenas en las que a modo de transición entre una secuencia y otra se intercalan planos de vistas panorámicas de los barrios y con frecuencia se ruedan en momentos de alba o en el crepúsculo para incrementar la carga emocional que aportan los momentos de inflexión. Este tipo de secuencia remarca, como apunta Balló (2000:184), la influencia que sobre la historia y los personajes va a tener el entorno representado.

La tipología de los personajes marginales es muy amplia, describiremos aquellas que nos resultan más interesantes. Sin establecer ninguna graduación por nivel de importancia destacan los siguientes personajes: el ama de casa, el delincuente juvenil, los ancianos y los jóvenes ambiciosos.

a) El ama de casa: son numerosísimas las representaciones que de este rol femenino se han hecho en el cine español. Sin embargo apenas encontramos papeles de protagonistas. Es por esto que ¿Qué he hecho yo para merecer esto?, resulte especialmente valiosa como reflexión acerca de la mujer, madre y ama de casa. 
A diferencia de las amas de casa de clase social media o alta:

- Raramente se les atribuye atractivo personal, son mujeres de mediana edad con las huellas del paso del tiempo y del trabajo.

- Pueden encargarse de la administración de la economía doméstica, pero habitualmente son los hombres, los cabeza de familia, los que lo hacen.

- Pueden aparecer amamantando a los hijos, y aún siendo la representación máxima de su condición de madre, este hecho solo aparece en el entorno marginal.

- Soportan la violencia de género de sus maridos con una resignación difícil de entender, paradigmático es el film Te doy mis ojos (Iciar Bollaín, 2003) o Solas (Benito Zambrano, 2000).

- Nos se las considera como individuos con derechos, como ciudadanas.

- Presentan con gran frecuencia una apariencia de agotamiento y cansancio que se convierte en característica inherente a ese rol.

b) La figura del delincuente juvenil aparece por primera vez en las producciones de los años cincuenta que intentaban reflejar la problemática social de nuestro país. Producciones como Día tras día (Antonio del Amo, 1951), Cerca de la ciudad (Luis Lucia, 1952), Segundo López, aventurero urbano (Ana Mariscal, 1952), Los Golfos (Carlos Saura, 1959) o Los chicos (Marco Ferreri, 1960). Son considerados victimas de la situación de pobreza tras la Guerra Civil. En las producciones más moralistas son los que hay que salvar, han sido maltratados y han sufrido privaciones importantes, por lo que suelen convertirse a su vez en maltratadores. Aparecen como componentes de grupos heterogéneos, algunos presentan rasgos definitorios pero en general son personajes muy similares unos a otros. Es a finales de la década de los setenta cuando reaparecen con fuerza estos personajes como protagonistas de numerosas realizaciones. Son jóvenes de entre trece y dieciocho años, cada vez acceden a la delincuencia antes y con una vocación delictiva más determinada. Presentan conductas muy violentas y una ausencia completa de remordimiento por sus acciones. Ya no tienen como anhelo cambiar de vida, sólo viven la vida que les es posible dado los condicionamientos que les impone su lugar de nacimiento.

c) Los ancianos: son junto a los niños los personajes que se presentan como los más débiles de la sociedad marginal. Los ancianos pierden parte de sus funciones sociales, no aportan ingresos económicos significativos. Tienen graves problemas de soledad y de afectividad. Estos se agravan cuando el individuo ha pasado la mayor parte de su vida, sobre todo su etapa formativa y productiva, en un medio rural y ha de enfrentarse en su vejez a un medio considerado hostil como es la ciudad. Suelen dar una visión más descarnada de la vida en la ciudad, sus reflexiones nos aportan una mirada crítica sobre los beneficios de la vida urbana.

d) Jóvenes ambiciosos: Son aquellos que entienden que su situación de marginalidad puede ser temporal y dedican todo su esfuerzo a conseguir salir de esta situación y ascender en el escalafón social. Un ejemplo acertado es el protagonista de El último sábado, (Pere Balañá, 1969) socialmente encarna un tipo de joven característico de Barcelona. Barcelona es la ciudad, donde suelen desarrollarse este tipo de historias, frente al pesimismo endémico de Madrid y el imposibilismo que representa la vida de provincias. Otras películas que ejemplifica esta situación es Young Sánchez (Mario Camus, 1963) o El espontáneo (Jordi Grau, 1966). La ambición en la mujer no está presente de forma significativa, sólo a partir de la década de los años noventa se inicia un cambio en el rol femenino, en películas como Antártida (Manuel Huerga, 1995), Mujeres al borde de un ataque de nervios (Pedro Almodóvar, 1988), Nadie hablará de nosotras cuando hayamos muerto (Agustín Díaz Yanes, 1995). 
El cine nos recuerda personajes característicos de épocas pasadas que al no darse en la actualidad se olvidan, tales como: la hija que queda soltera para cuidar de los padres durante la vejez; el casero sin escrúpulos que amasa riquezas a costa del penar de los pobres que malviven en sus propiedades; la pariente pobre y desamparada al borde de la línea de la cordura a la que se trata como una criada; los guardeses de las fincas de los señoritos; la servidumbre; las personas que no tienen hogar propio y conviven en habitaciones realquiladas o en pensiones; las casas de citas; el tío solterón que convive con la familia; el padrino que ejercía de segundo padre.

\subsection{Familias}

La representación que se hace de la familia en la cinematografía española es bastante homogénea. Si bien el análisis efectuado por los cineastas de la familia, como núcleo vertebrador de la sociedad tradicional española, ha sido fecundo y nos permite seguir durante el siglo de historia del cine las variaciones que esta ha experimentado.

Durante la década de los años treinta, con la Segunda República, el cine que se revela como un excelente difusor de las ideas y permite el progreso cultural de masas de población analfabeta o de escasa formación. Son numerosas las películas que empiezan a difundir nuevas imágenes de la mujer, de las relaciones sociales y por supuesto del papel de la familia tradicional. Producciones como: La hija de Juan Simón (José Luis Sáez de Heredia, 1935), en la que la protagonista es madre soltera, pero rehace su vida con su novio y en la que no hay ningún tipo de juicio moral sobre la conducta de la protagonista, sino que se reprueba la conducta de los padres que someten a una vida desgraciada a su hija por intentar ocultar su desliz a la sociedad que condena toda conducta fuera de la moral tradicional; Don Quintín el amargao (Luis Marquina, 1935) que por celos infundados condena a su esposa y a su hijo a una vida de mendicidad, en ella vemos como, de la conducta de un cabeza de familia tirano, resulta la desgracia del resto de los familiares; en Morena Clara (Florián Rey, 1936) se muestra la posibilidad de un matrimonio interclasista e interracial.

Durante la siguiente década después de la Guerra Civil, el cine se encarga de rehacer la imagen de la familia tradicional. Se hace exégesis de los valores fundamentales de la familia y sobre todo del rol de la mujer en la nueva sociedad española de los cuarenta. El tema de la honra de la mujer vuelve con fuerza a las pantallas y asistimos a la pérdida de independencia de las heroínas de las películas. Siguiendo esta pauta hay producciones como: Raza (José Luis Sáez de Heredia, 1941) en el que el guión de Francisco Franco pretendía establecer el canon de cómo se habrían de tratar asuntos como la Guerra Civil o «la familia española; y como Alma de Dios (Ignacio F. Iquino, 1941) en la que se estigmatiza a las madres solteras; Balarrasa (José Antonio Nieves Conde, 1950), en el que la idea falangista del influjo negativo de la ciudad en las familias nos presenta a un religioso que se encarga de recomponer su situación familiar; La aldea maldita (Florián Rey, 1942) en la que una madre desnaturalizada abandona el núcleo familiar y trae la desgracia para sus componentes.

En la década de los cincuenta aparece nuevamente el tema familiar desde una óptica diferente. Las familias vuelven a la moral católica y se presentan cohesionadas para enfrentarse a numerosas vicisitudes provocadas por la coyuntura económica y social en la que se encontraba España. En Esa pareja féliz (Luis García Berlanga y Juan Antonio Bardem, 1951) vemos a una pareja obrera con sus necesidades y anhelos, sometida a todo tipo de carencias (vivienda, trabajo, dinero...). En El Inquilino (José Antonio Nieves Conde, 1957) la pareja protagonista pierde su hogar a consecuencia de una orden de des- 
ahucio por el derribo de su vivienda que amenaza ruina. Por su parte, la mirada que sobre la familia española efectúa el realizador italiano Marco Ferreri en El cochecito (1958) y en Los chicos (1959) revela otros aspectos característicos de la idiosincrasia de la familia española, extraños para la mirada de un extranjero.

A partir de los años sesenta la familia española ya está plenamente definida y descrita, pero no deja de aparecer como elemento fundamental en la filmografía de nuestro país. Cabe destacar como referencia significativa la serie de películas que sobre la «familia numerosa» se ruedan en pleno fenómeno del Baby boom; entre las que destacan La gran familia (Fernando Palacios, 1962), La familia y uno más (Fernando Palacios, 1965).

Los procesos de desintegración familiar son asunto fundamental en el cine español, se abordan tanto las historias de familias concretas como la degradación de la institución familiar.

Las familias provenientes de ambientes rurales que emigran a la ciudad suelen sufrir procesos de desmembración que se explican por las diferentes aspiraciones de sus componentes.

En numerosas historias sobre individuos marginales las familias aparecen como quimeras salvadoras, en ellas reside la última o la única oportunidad de aquellos que han perdido cualquier otra posibilidad de auxilio.

\subsection{Códigos de conducta}

El cine, junto a la literatura, se muestran como las únicas fuentes capaces de ilustrar sobre las cuestiones de las que normalmente no queda rastro documental. Son las concernientes a los usos y costumbres sociales, a las relaciones personales y a los códigos que las rigen.

La subjetividad es el rasgo fundamental en la percepción de estos fenómenos. Por un lado la elección de los asuntos a desarrollar por parte de los cineastas ya impone una carga subjetiva, a lo que hemos de añadir su formación, el contexto social en el que se desarrollan, la legislación vigente con su imposiciones vitales y la posibilidad de mostrar estos procesos con libertad de expresión.

Debemos por lo tanto acotar el ámbito de análisis. Por una parte, en las películas se encuentran asuntos que son del interés personal del director o del guionista. En estos casos las informaciones que se ofrecen están condicionadas por la personalidad de estos, pero ello no es motivo que atenúe la validez de las informaciones que ofrecen. Y por otra parte la opinión pública, o el conjunto de opiniones que se expresan por el público, aquello que trata de la res publica, argumentos de naturaleza pública: los intereses generales, el bien común, los problemas colectivos, las costumbres o las actitudes universales.

Como afirma Giovanni Sartori (2003:73) «la opinión pública es un dato que se da por descontado. Existe y con eso es suficiente. Es como si las opiniones públicas fueran, como las ideas de Platón, ideas innatas». La opinión pública tiene dos relaciones diferenciadas, pero de suma importancia para el cine, por un lado acepta que el cine sea el reflejo de las ideas generalizadas de una sociedad, y por ello permite conocer cuales son aquellas ideas que generan de manera colectiva un grupo, una sociedad o una nación; es en este aspecto en el que se basa parte del valor documental del cine. Pero por otro lado el cine es un instrumento de primer orden en la formación de la opinión pública, con una gran relevancia, que sólo pierde con la aparición de la televisión. La propaganda de los gobiernos a través del cine ha sido usada desde los comienzos del cine como espectáculo de masas. Y por esto mismo, el cine sirve para saber cual es el ideario que los gobiernos intentan imponer a los gobernados. 
Son innumerables los mensajes lanzados a través del cine, así como las opiniones recogidas en las películas. Hacer su inventario pormenorizado excede el objeto de este texto, pero si cabe resaltar algunos aspectos destacables:

- En los barrios marginales no rigen las leyes morales de la ciudad. Sus habitantes, sometidos a las más deplorables condiciones vitales, pueden saltarse las convenciones morales que rigen para el resto de los ciudadanos. Pueden verse conductas que no aparecen en otros estratos sociales: relaciones prematrimoniales, cohabitación, adulterio, adicción a drogas,...

- Mientras que para las clases medias o altas, la mayoría de las realizaciones pretenden mostrar una imagen de la felicidad, vidas llenas de sonrisas, relaciones infantiloides, ñoñeria, mitificación de lo aristocrático, exaltación de lo material, valoración extrema del éxito, etc; lo triste y lo misérrimo es inherente a lo marginal.

- Se puede constatar que existe una diferenciación en las relaciones sociales en los diferentes territorios que componen España. Se observa una mayor jerarquización de la sociedad castellana, no así en Cataluña, País Vasco y País Valenciano, esto es, las zonas más industrializadas, en las que las posibilidades de ascenso social a través del trabajo se muestran más igualitarias en el trato a los individuos procedentes de entornos marginales.

- En cuanto a las relaciones entre ambos sexos, el machismo es la tónica imperante aún en las producciones más recientes. Sólo en las producciones durante la Segunda República Española puede observarse un intento de educar en el sentido de abandonar las concepciones machistas. En este sentido sería muy interesante desarrollar en profundidad el análisis tanto del lenguaje como de las representaciones visuales del sexismo. Algo que ha de resaltarse es la ausencia de condena moral en las escenas en las que puede verse palizas a esposas, lo que actualmente se denomina violencia de género. Se da hasta los años sesenta la representación de la mujer como una propiedad del varón con la que puede usar los golpes para su educación.

- En cuanto a las relaciones de pareja, la información que se obtiene es tanto cuantitativa como cualitativamente importante.

\section{Otros aspectos de la marginalidad a través del cine}

\subsection{Inmigración}

La atracción que la imagen de la ciudad tiene en el emigrante rural responde a la idea que se forman las comunidades rurales de la vida en la ciudad. El conocimiento del tipo de vida urbano se adquiere por las referencias de aquellos que ya han emigrado, pero también por la imagen que el cine trasmite de la vida en la ciudad. A este respecto resulta significativo que en el estudio de Miguel Siguan (1957:209) sobre el éxodo rural, se planteó la posibilidad de realizar complementariamente a la encuesta a las familias emigradas unos cuestionarios sobre la emigración realizados en los lugares de origen. Dicha encuesta no llegó a realizarse pero en el estudio se incluye el cuestionario que se preparó. La pregunta número catorce de dicho estudio es «¿Influye el cine sobre la inmigración?». Las declaraciones y detalles sobre la vida de los inmigrantes recogidas en las entrevistas de este trabajo, realizado en el año 1957, resulta de una similitud asombrosa con las producciones cinematográficas contemporáneas. En los casos de Surcos y El pisito las analogías son muy significativas. Por lo que este trabajo ha resultado de gran relevancia para comprobar la realidad de estas historias elaboradas y recreadas con situaciones verificables documentalmente. 
El emigrante ha generado habitualmente animadversión en los habitantes autóctonos, es una reacción de temor ante la idea de que la ciudad sea incapaz de procurar sustento para todos. En Surcos en una de sus primeras escenas hay un ejemplo claro de cual era el recibimiento que se le profesaba a aquellos que llegaban a la ciudad. Este sentimiento de rechazo es mucho mayor en Madrid que en Barcelona. En la Ciudad Condal es de mayor relevancia el dato de la integración, de la asimilación idiomática, en El último sábado al protagonista le preguntan si habla catalán y contesta «no, soy castellano, nacido en Barcelona». Con respecto a la utilización del catalán en las películas anteriores a la década de los setenta, es más frecuente de lo que cabría suponer. Producciones madrileñas como Aeropuerto (Luis Lucía, 1953) o en Los Golfos (Carlos Saura, 1959), aparecen personajes hablando en catalán. En las producciones barcelonesas se utiliza para diferenciar social y culturalmente los personajes.

A los personajes de inmigrantes se les caracterizaba por el vestir, por el hablar y por el miedo y la inseguridad que la ciudad les trasmite. Según entrevista a José Antonio Nieves Conde de Francisco Llinas (1995:81), en alguna producción compró ropas a transeúntes con las que vestir a los protagonistas para resaltar un aspecto realista. Resulta interesante saber que la representación estereotipada que del paleto se hace en el cine no era, siempre, caricaturesca sino que en muchos casos es muy cercana a la realidad de los años cuarenta y cincuenta. Según declaraciones de Jorge Semprun a los refugiados españoles en Paris tras la Guerra Civil Española se les detenía al ser reconocidos por el miedo que les producía el tráfico al cruzar las calles de la capital francesa.

Además de para huir de la pobreza, muchos individuos cambiaros sus residencias a la ciudad para huir de las represalias de sus vecinos por pertenecer al bando republicano durante la Guerra Civil, en Mambrú se fue a la guerra (Fernando Fernán Gómez, 1986), el protagonista pasa escondido toda la postguerra en un sótano de su casa. Para la mujer la ciudad no supone una huida del rol que se le tenía asignado, la ciudad solamente supone cierta mejora en las condiciones materiales de vida y el acceso a algunas comodidades como vemos en Alma de Dios. La representación más típica de inmigración femenina lo suponen las chicas de servicio, aparecen frecuentemente, tanto como protagonistas como personajes secundarios, a partir de los años sesenta en realizaciones como: La ciudad no es para mi (Pedro Lazaga, 1966), Las que tienen que servir (José María Forqué, 1967), Como está el servicio (Mariano Ozores, 1968), La casa de los Martínez (Agustín Navarro, 1971).

Los medios por los que llegan a la ciudad los emigrantes presentan algunas características curiosas: En algunos casos la emigración se hace a pié; a Barcelona se muestra la llegada en algunas ocasiones en barco, lo que incide en el carácter de puerto de mar de la ciudad; a Madrid se llega sobre todo en tren.

Cuando la emigración es familiar, primero suelen emigrar los varones en edad de trabajar y cuando estos han podido conseguir vivienda lo hacen las mujeres. También se da frecuentemente el caso de que emigra la familia completa. Al llegar a la ciudad se dirigen a la casa de algún familiar emigrado con anterioridad. Normalmente las casas de la ciudad tienen peores condiciones que las que dejaron en el pueblo. La emigración no supone a los padres de la unidad familiar un cambio considerable en sus conductas. Su vida social se muestra muy reducida y al trasladarse a un medio extraño aumenta su impresión de aislamiento. No leen prensa, no van al cine. Su aclimatación resulta dificultosa y suelen conseguirla con la ayuda de los hijos. Los ancianos muestran siempre el deseo de morir en el pueblo.

En las producciones actuales la inmigración ha cambiado. Es inmigración de individuos procedentes de países africanos, asiáticos y sudamericanos, que aportan situaciones de multiculturalismo y de diversidad étnica. Igualan el paisaje humano de nuestras ciudades a las del resto del mundo occidental. En general las películas denuncian las condiciones 
inhumanas tanto en la situación material de estos individuos como el trato que reciben. El cine a servido para acercar la imagen de los inmigrantes, recordar al público que se trata de personas con singularidades e historias personales, cabría significar producciones como: Flores de otro mundo (Iciar Bollain, 1999), Bwana (Imanol Uribe, 1996), Las cartas a Alou, (Monxto Armendáriz, 1990).

La inmigración es el fenómeno que marca el carácter marginal de los barrios con relativa frecuencia, la recepción por parte de las ciudades de población que abandona su lugar de origen huyendo de las condiciones desfavorables conforma grupos humanos homogéneos, con similares situaciones vitales, similares deseos, con mecanismos de defensa que se desarrollas para sobrellevar unas existencias difíciles.

\subsection{Delincuencia}

La delincuencia pervive como medida de higiene social. Erradicarla por completo sería universalizar el sistema penitenciario y convertirlo en el entorno para todos, a modo de la sociedad propuesta en Un mundo feliz de Aldous Husley o mejor una sociedad vigilada como en la novela 1984 de George Orwell. La delincuencia es parte misma de la vida marginal, sobre su moralidad no hay juicios de valores ni arrepentimiento. Es una forma de salir adelante, forma parte de lo cotidiano de la misma forma que lo puede ser el trabajo por cuenta ajena.

El cine que transcurre en barrios marginales ha representado sobre todo delincuencia juvenil. En las sociedades modernas cada vez se distancia más el hecho de la madurez biológica, que coincide con la pubertad, de la madurez social, que sería el momento en que el individuo comienza a adquirir plenas responsabilidades. Por lo que la delincuencia juvenil se incrementa en función de la falta de adecuación entre la posibilidad y el acto de formar parte del engranaje social. Lo delictivo, asimilado a lo irresponsable, se presenta como una de las posibilidades de desarrollo del individuo joven que no encuentra otra solución a su aislamiento social. El grupo es el factor que facilita la incorporación del joven al mundo social, y a través del grupo también al mundo del delito. Los mayores índices de delincuencia se dan en las zonas más urbanizadas. En estas se instalan los mecanismos del delito de forma que las estructuras delictivas perviven gracias a los relevos generacionales.

En el cine aporta como información no sólo la tipología de los delitos, sino la metodología empleada en la ejecución de los mismos. Podemos ver como se asaltan hogares, bares, mercados, con o sin violencia, o como es el tráfico de drogas o armas.

El cine durante su historia ha puesto a la vista del público en general procesos o mundos ocultos completamente desconocidos. Muchas películas constituyen un resumen del estado de la cuestión legal alrededor de la delincuencia, son un catálogo de delitos y de cómo como cometerlos, sus penas legales, como evitarlas, etc.

Dentro de la tipología de delitos representados por el cine, la prostitución sería el más numeroso. Uno de los aspectos más relevantes en su representación es la ausencia de condena moral. En la gran mayoría de las situaciones ni se le otorga la condición de hecho delictivo, y por supuesto, no se identifica al cliente como el que está cometiendo el delito. En muchas realizaciones la prostitución es mostrada como el castigo que le corresponde a la mujer pecadora, esto es, a la que no ha conservado la honra, en el cine se repite una historia de forma recurrente: mujer joven mantiene relaciones con su novio, queda embarazada y por cualquier circunstancia del destino no se casa, esto supone su deshonra y la de su familia, su destierro y descenso a los infiernos de la ciudad, a la prostitución y en un alto porcentaje de casos la muerte. Como ejemplo de esto podemos citar: La aldea maldita (Florián Rey, 1942), Centinela alerta (Jean Grémillon, 1936), El padre pitillo 
(Juan de Orduña, 1953). En las películas actuales la prostitución está ligada al mundo de la drogadicción, son mujeres con un deterioro físico considerable.

En algunas producciones de la etapa de la Dictadura, la ciudad trasmite la idea de peligrosidad, tanto para sufrir los delitos como dada la degradación moral existente en los llamados entonces «barrios bajos» o «bajos fondos», donde el delito es más frecuente que el trabajo honrado, y donde las tentaciones para caer en lo ilícito son constantes, ejemplos podemos encontrar en: La calle sin sol (Rafael Gil, 1948), Los atracadores (Francisco Rovira Beleta, 1961), Distrito quinto (Julio Coll, 1957), Delincuentes (Juan Fortuny, 1956), Camino cortado (Ignacio F. Iquino, 1955).

En ocasiones el botín del delito no es para cubrir necesidades básicas, se malgastan para conseguir momentos de opulencia que hagan olvidar la situación de miseria cotidiana. Los pequeños hurtos corresponden a caprichos que los personajes no pueden permitirse, se trata de pequeñas revanchas contra la sociedad.

El aumento de la delincuencia que se dio al inicio de los años ochenta, que en opinión de los nostálgicos del régimen anterior era culpa de la Democracia, fue asunto principal de un gran número de producciones.

La delincuencia es en muchos casos el modus vivendi por el que optan muchos individuos que habitan los espacios marginales. Moralizar sobre su condición ha sido frecuente en las producciones cinematográficas hasta los años ochenta, ejemplos de otra visión como Cerca de la ciudad, con una mirada paternal y religiosa, o Los tramposos (Pedro Lazaga ,1959), donde aparece con cierta ternura el delincuente de poca monta, son una muestra de la diversidad potencial de miradas que el fenómeno suscita desde el cine.

\subsection{Pobreza}

La ciudad ha representado durante el siglo XX la imagen de la prosperidad y de la riqueza. La urbanización de la sociedad española se ha producido en parte por la instalación de la industria y más tarde los servicios como motores económicos en sustitución de las actividades primarias y en parte por el atractivo que la ciudad representaba en el mundo rural. La comodidad, las oportunidades de enriquecimiento, el lujo,... es la imagen soñada. La imagen del barrio marginal, de la pobreza, del paro, de la delincuencia se autosustrae para afianzar el convencimiento de que la vida urbana es superior en calidad a la rural. En la actualidad los emigrantes de los países del tercer mundo arriesgan sus vidas para llegar al mundo occidental con la esperanza de vivir de acuerdo a la imagen formada a través de los medios de comunicación (cine y televisión fundamentalmente), sin conocimiento real de lo que será su situación al llegar al primer mundo. Huir del hambre y la pobreza es el motor de la mayoría de las migraciones humanas.

En las ciudades existen siempre bolsas de pobreza. El grado de la misma depende de la coyuntura general, pero el sentimiento de pertenecer a un estrato social bajo se haya presente en los individuos que habitan en los barrios marginales. Percibir la propia situación vital como pobre no está relacionado exclusivamente con el hambre, el no tener cubiertas las mínimas necesidades vitales es la más extrema de las situaciones del sentimiento de pobreza. La carencia de una vivienda digna es otro de los factores principales para sentir la pertenencia a una situación marginal y de pobreza. En esta percepción influye también la consideración social del entorno inmediato. Los procesos de hambruna pueden haber finalizado pero perpetuarse en los barrios una situación de delincuencia, violencia y degradación de las infraestructuras que configuran los paisajes de la pobreza.

En el cine se puede confirmar que la pobreza se vive como un estado de ánimo, más que como un estado material. Si se observa cual es el equipamiento de los hogares de los 
barrios marginales en algunas películas españolas sorprende que los personajes se sientan pobres. Es quizá el temor de no cambiar nunca, de estar condenados a vivir siempre en una situación conocida. Durante la década de los años sesenta en Barcelona y en los ochenta encontramos algunos ejemplos de joven que progresa y consigue un ascenso social.

Resulta muy interesante cuando en alguna realización se da el contraste entre los dos mundos, ricos/pobres. Suele hacerse uso de los tópicos más ramplones imaginables, son usualmente visiones de situaciones marginales distorsionadas desde un estadio burgués, malentendidas y excesivamente melodramatizadas, e incluso, muy frecuentemente envueltas de un cierto halo folclórico. La imagen que el individuo marginal tiene del mundo rico es muy parcial y se centra exclusivamente en la sustitución de sus carencias por una situación de extremo bienestar.

\subsection{Violencia}

El recurso a la violencia y delincuencia en las producciones cinematográficas se utiliza normalmente para activar los mecanismos del miedo en el espectador. Un miedo que traspasa hasta la vida cotidiana y que se instala en el ideario colectivo, gracias a que la situación descrita se presenta como una traslación a la pantalla de una situación real.

El uso de la violencia física en las películas españolas es muy reciente. Llega como consecuencia de la influencia de determinado tipo de producciones estadounidenses. En esta filmografía el término marginal esta indisolublemente asociado al de violencia, en muchos casos el carácter de ésta es extremo. Realizadores como John Singelton o Spike Lee, que han tratado el mundo de los barrios negros en Los Ángeles y Nueva York respectivamente, hacen de la violencia el aglutinante de todas las historias.

En el caso de las producciones del País Vasco, a partir de los ochenta, presentan una juventud violenta. Son la nueva generación que ha surgido inmersa en la violencia etarra, como vemos en las películas de Daniel Calpasoro. Forman parte de las organizaciones violentas cuando sus convicciones políticas les llevan a ello o simplemente tratan de sobrevivir en un medio hostil. En estas películas resulta explicita, incluso se recrean en su estética. Se muestra aquello que es habitual en determinados ambientes marginales, pero que se encuentra lejos de la visión frecuente del espectador. Lo aplastante de las escenas violentas es un recurso para provocar la intranquilidad en el público y ubicarlo en la situación vital de los personajes.

La falta de amabilidad en el trato y la violencia verbal está presente en toda la filmografía española que trata el hecho marginal. Es el reflejo de una sociedad frustrada, sin porvenir, ni alegrías que descarga la agresividad acumulada en todo momento, se da de manera continua entre los jóvenes que descargan la agresividad en un lenguaje osco. Este tipo de lenguaje se generaliza en las películas españolas de los años cincuenta. Se utiliza la violencia verbal con el similar o inferior, raramente con el que se encuentra en una situación superior. El mal humor como actitud, la dificultad de entendimiento y la incomunicación se debe a una interiorización absoluta de los sentimientos personales que marcan las relaciones entre todos los personajes.

\subsection{Los toxicómanos}

Las grandes adicciones, a cualquier tipo de sustancia (drogas o alcohol), tienen como consecuencia, cuando el control de las mismas excede la voluntad del individuo, la inserción en el mundo de la marginalidad, como magistralmente muestra en Días de vino y rosas (Billy Wilder, EEUU, 1962). 
En su relación con las drogas la marginalidad puede ser tanto destino como origen, las condiciones que se dan en los ambientes degradados son fundamentos para el fomento del consumo de drogas. El cine ha descrito hasta la saciedad como son los procesos de la relación de individuos, sobre todo jóvenes, con la droga, un ejemplo muy profuso en información sería El pico (Eloy de la Iglesia, 1983) y El pico 2 (Eloy de la Iglesia, 1984).

El toxicómano, en sus primeras fases o cuando pretende ocultar su condición, no tiene una caracterización especial, pero a través del cine hemos conocido aquellos aspectos que los singularizan, como el que se ve a través de la historia de la protagonista de Antártida: irritabilidad, falta de concentración, vómitos tras la ingesta, etc.

Los toxicómanos en fase avanzada, como el personaje que interpreta Jordi Mollá en La buena estrella (Ricardo Franco, 1997) son representados como auténticos despojos humanos, a los que además de los signos de decrepitud propios del consumo de drogas, se une las señales de las enfermedades que van anexas a este proceso: hepatitis, tuberculosis y SIDA. Son potenciales delincuentes, su presencia es incómoda en los ambientes no marginales, provoca similar rechazo al de aquellos que padecían las enfermedades históricas (peste o lepra), sólo cuando son personajes protagonistas son recuperables para la sociedad, como en Martín H (Adolfo Aristaráin, 1996).

\subsection{Ocio y lugares de reunión}

A las relaciones sociales en los países mediterráneos se les ha concedido mayor importancia que en otros espacios geográficos. Algunas de las palabras más conocidas del idioma español son fiesta, flamenco, toros ,... palabras asociadas a lo lúdico que denotan a esta sociedad como fuertemente predispuesta al disfrute y al ocio.

En los entornos marginales las posibilidades de disfrute del ocio y las posibilidades económicas deberían significar una traba para el desarrollo de una vida social intensa. Como podemos corroborar en la filmografía española no siempre sucede así. Encontramos lugares para la reunión, la sociabilidad y el ocio realmente singulares.

La calle es el gran espacio de la sociabilidad, gran parte de la vida se desarrolla fuera de las viviendas, incluso en aquellos lugares de climatología más desfavorable. Los niños ocupan el espacio público de manera preferente, pero no exclusivamente. Incluso las puertas y aledaños de los bares y locales de ocio son usados prioritariamente al interior de los locales.

Las periferias de las ciudades son lugares de paseo que aparecen con gran frecuencia en las películas españolas. La escena más recurrente es aquella en la que la vista de la ciudad aparece frente a los personajes, mostrándola como la prisión de la que sólo se escapa momentáneamente.

El grado en que participan del carácter urbano condiciona su nivel de calidad como espacio de ocio. Los espacios vacíos pero anexos a las zonas urbanizadas, los descampados, son lugares fundamentales en las relaciones sociales de los entornos marginales, son paisajes desoladores, en los que se acumulan desechos, frecuentemente cruzados por vías de tren o carreteras, pero en los que la ciudad desaparece, los personajes pueden desarrollar su libertad individual sin la presión de la cotidianeidad, de las leyes, de la civilización y sus agentes y consecuencias. En estos lugares la sociabilidad se puede dar, pero en ellos no es necesario el consumo, son los espacios para una juventud sin recursos.

Aunque sin duda alguna los grandes templos de la sociabilidad hispánica son los bares. Se podría llegar a afirmar que no existe película española rodada en ciudad que no incluya alguna escena que se desarrolle en un bar. El bar es el lugar de la confidencia, de los negocios, el sitio donde matar el tiempo. Los parados salen de sus casas para estar 
en el bar, podemos ver en Los lunes al sol (Fernando León, 2002). En el cine español podemos encontrar la tipología completa estos locales.

El cine y el teatro, aparecen habitualmente, pero en el hecho de que se haya de pagar hace que, para personajes marginales, éstos sean un producto de lujo y su uso no sea tan frecuente. En el caso de los personajes provenientes del ámbito rural es raro el hábito de frecuentarlos, son los individuos urbanos los que acuden mayor frecuencia.

La sociedad española que paradójicamente se ha ido acercado a una alfabetización universal ha perdido los hábitos de lectura paulatinamente durante todo el siglo XX. La cultura de la imagen ha ido desplazando a la de la palabra escrita. Por este motivo librerías, quioscos y bibliotecas dejan de ser lugar de encuentro como podíamos encontrar en producciones de la primera mitad del siglo.

En el numerosas películas podemos encontrar información sobre lugares de reunión muy populares en algún tiempo como fueron los recreativos, bailes o discotecas.

\subsection{Actividades económicas}

«Todo es cuestión de dinero», esta frase en boca de uno de los personajes del grupo de Los golfos, nos significa que son los grupos marginales los que de forma más dura sufren los periodos de crisis y los fracasos de la nueva economía capitalista, liberal y mercantilista a la que incorpora España a lo largo del siglo XX.

La construcción es la principal actividad económica de la que obtenemos información. Los inmigrantes cuando llegan a la ciudad suelen encontrar su primer empleo como peón de obra y más difícilmente en la industria aunque esta presentaba muchas ventajas sobre el peonaje en la construcción, en los años cincuenta, en cuyas producciones encontramos mayor número de informaciones podemos constatar que los personajes preferían la colocación en una industria ya que:

- No solía tratarse de empleo eventual.

- Un mayor sueldo. Si como peón en la construcción en la década de los 50 el salario base era de 1.080 pesetas mensuales, en la industria se podían alcanzar las 2.500 pesetas mensuales.

- Había una mayor comodidad en el trabajo.

- Se disponía de seguridad y asistencia social.

Las labores relacionadas con el mundo de la construcción aparecen profusamente descritas en un gran número de producciones. En construcción (José Luis Guerín, 2000) es el ejemplo máximo ya que durante dos horas asistimos al proceso de derribo y reconstrucción de un inmueble, y podemos ver con todo lujo de detalles los procesos que ello comporta.

Hasta que no se da la industrialización de España, los lugares de trabajo se muestran como continuación del hogar, son ambientes casi familiares, donde incluso se come, la figura del jefe suele presentarse como la de un padrecito, no siempre este término tiene connotaciones positivas, al que se le pide consejo dada su supuesta mejor formación y mayores conocimientos de la administración, la burocracia suponía un muro infranqueable para aquellos que no disponían de formación.

Los mercados aparecen abundantemente en la cinematografía española. Tenemos representaciones de todo tipo de ellos. Es en los pocos ámbitos donde podemos encontrar a la mujer dentro del sistema económico de una manera normalizada.

En las realizaciones ubicadas en Barcelona, aparecen con mayor frecuencia actividades fabriles. Es una de las señas de identidad de la Ciudad Condal, en El último sábado, las 
primeras escenas de la película trascurren en una editorial, de manera casi documental se muestran todos los procesos que de una fábrica de este tipo. Y no sólo esto sino que también aparecen ejemplos de cómo era las relaciones entre los trabajadores y el patrón, así como los movimientos asociativos de los empleados. Tanto el asociacionismo sindical como el meramente lúdico. Es también en Barcelona donde encontramos plenamente integrada en las labores productivas a la mujer.

\section{Aporte documental}

El cine español desde muy pronto suscitó, en los diferentes gobiernos, el interés por controlar un medio de comunicación de masas de un potencial informativo cualitativo y cuantitativo muy importante. El Ministerio de la Gobernación en 1912 emite un Real Decreto por el que se impone la primera regulación de las exhibiciones, en el que se insta a los productores a poner atención a la existencia de un público joven, aboga por la búsqueda de lo instructivo y educador en el cine e intenta promover las sesiones especiales matinales. $\mathrm{Y}$ al siguiente año instaura la solicitud de censura previa al rodaje. Desde este momento y aún durante la Segunda República española no existe una actuación decidida por parte de los gobiernos sobre el cine, existe una censura nominal que no está lo suficientemente institucionalizada, no hay una legislación que la regule y su actuación es ambigua. Pero es a partir del golpe de estado del general Francisco Franco cuando se comienza a institucionalizar el control sobre el medio cinematográfico. Una Orden de 21 de marzo de 1937 creó los Gabinetes de Censura Cinematográfica de Sevilla y de la Coruña. En Orden de 19 de octubre se dispone que estos pasen a depender de la Delegación del Estado para Prensa y Propaganda. Y el 18 de noviembre de 1937 otra Orden crea la Junta Superior de Censura Cinematográfica con sede en Salamanca. La censura definitivamente fue regulada por la Orden de 2 de noviembre de 1938, que establecía una Comisión de Censura Cinematográfica y una Junta Superior de Censura Cinematográfica.

La institucionalización de la censura en España supuso la creación de un Archivo en el que se guardase toda la documentación que esta burocracia generase. El archivo pasó a formar parte del Ministerio de Cultura una vez fueron derogadas las leyes que imponían la censura. Este archivo se incorporó recientemente al Archivo General de la Administración sito en Alcalá de Henares dentro de lo que se denomina Fondos de Cultura. La documentación generada durante cuarenta años de censura reglada, se organiza en dos tipos de expedientes, el de censura y el de rodaje. En los primeros se guarda la documentación oficial de censura previa del guión, la deliberación de la Junta de Calificación con la asignación de categoría, los permisos oficiales de rodaje, estreno y distribución y la censura definitiva una vez finalizado el rodaje de la misma. Además contiene también cualquier incidencia que pudiera ocasionar esta gestión, esto es, modificaciones impuestas tanto al guión como al material definitivo, inconvenientes que pudiese plantear las autoridades eclesiásticas o autoridades de cualquier instancia de la administración. También los informes de las Delegaciones del Gobierno en las distintas provincias donde se estrenaba el film. Y lo que resulta más interesante, se incorporan a estos expedientes artículos de prensa que contienen no sólo las reseñas cinematográficas de las películas sino también informaciones relativas al estado de la cuestión, a la opinión pública, a la actuación del gobierno en los asuntos tratados argumentalmente en las realizaciones. De este modo se puede encontrar en el expediente de censura de El inquilino, recortes originales de artículos de prensa titulados «Hoy, Día de la Plegaria por la Vivienda» Diario Ya, 11 de enero de 1959, «En España hay un millón doscientas mil familias sin hogar» ABC sábado 22 de noviembre de 1958, «El estado dedica cinco mil millones de pesetas al año para viviendas» Arriba, sábado 22 de 
noviembre de 1958. Atendiendo a la documentación que se encuentra en los expedientes de censura de aquellos filmes que tuvieron incidencias con la administración, podemos, no sólo analizar geográfica o cinematográficamente los asuntos en ellos contenidos, sino que se puede también reconstruir el contexto social, económico y político en el que dicho film surge.

Los expedientes de rodaje almacenan toda la documentación administrativa que genera una película durante su producción. Solicitudes de permisos varios, presupuestos, plan de rodaje, licencias de doblaje para las distribuidoras y cuentas definitivas. Pero resulta muy interesante la información que sobre los enclaves de rodaje encontramos en ellos. Estos expedientes nos permiten localizar los lugares donde se han llevado a cabo las tomas que aparecen en las películas. Ello nos permite distinguir entre localizaciones originales y decorados (no siempre resulta sencillo hacer esta distinción).

\section{Bibliografía}

BALLÓ, J. (2000): Imágenes del silencio. Los motivos visuales en el cine, Editorial Anagrama, Barcelona.

BAUDILlARD, J. (2000): Pantalla total, Anagrama Colección Argumentos, Madrid.

FANÉS, F.(1989): El cas CIFESA: vint anys de cine espanyol (1932-1951), Valencia Ediciones Filmoteca, Valencia.

FILMOTECA VASCA (1990): Euskal Zinema, Filmoteca Vasca. Gobierno Vasco - Departamento de Cultura y Turismo, San Sebastián.

LLINAS, Francisco (1995): José Antonio Nieves Conde. El oficio de Cineasta, Semana Internacional de Cine de Valladolid, Valladolid.

MONTERDE, J.E. (1995): «Continuismo y disidencia (1951-1962)», ap. Román Gubern et al., Historia del Cine Español, Editorial Cátedra, Madrid.

ROMAN G., MONTERDE, J., PÉREZ PERUCHA, J., RIAMBAU, E., TORREIRO C. (1995): Historia del Cine Español, Editorial Cátedra, Madrid.

SARTORI, G. (2003): Hommo videns, Editorial Edisa, Madrid.

SIGUAN, M. (1957): Del campo al suburbio. Un estudio sobre la inmigración interior en España, Junta de Estudios Jurídicos y Económicos, Madrid.

TORREIRO, Casimiro (1995): «Del tardofranquismo a la democracia (1969-1982)», ap. Historia del cine español, Roman Gubern, José E. Monterde et al., Madrid, Cátedra, col. Signo e Imagen, 1995, pp. 341-397.

TRASHORRAS, A.(1998): «Érase una vez en el Barrio», Roberto CUETO (coord..) Los desarraigados en el cine español, Festival Internacional de Cine de Gijón, Gijón. 
